\title{
Kaius Tuori Lawyers and Savages. Ancient History and Legal Realism in the Making of Legal Anthropology
}

(Routledge, New York, 2015, pp viii and 224, Hbk 978-0-415-73701-2 (\$ 101.04) and ebk 978-1-317-81620-1 (\$ 54,95))

Tuori has the good fortune to have had the opportunity to study history, law and anthropology, which has equipped him to dive into the nouvelle vague of interdisciplinary research. In consequence, his latest book analyses the rise and fall of legal primitivism following the work of pioneers in a wide variety of disciplines. Focusing on the trilogy of sex, greed and violence, the narrative takes us from the Americas to Australia, Greenland, Africa and further. Greed is represented by the paradigmatic variations played on the theme of the development of ownership of land and contract; sex stands for the Dichtung und Wahrheit spun around matriarchy, promiscuity, polygamy and the "civilised" monogamy, while violence hovers in vendetta, feud, honour killings and blood revenge. Within the tales about these themes the reader meets old friends like the brothers Grimm, von Savigny, von Jhering, Fustel de Coulanges, Maine and Schiller, but is also introduced to a sparkling variety of new authorities such as Martius, Lonröt, Bachofen, Malinowski, Boas, Llewellyn and Gluchkman to name but a few.

The subtext of the book is continuity and change of beliefs and the theories built upon them. Continuity is epitomised by the fundamental credo of progress. This thesis had already formed part of the cultural heritage of the young Cicero (De inventione 12 ) and was resurrected by humanism and developed into a cornerstone of religion and communism. Tuori sets out how new discoveries during the nineteenth century gave new impetus to evolutionism and led to the development of grand theories. As Gulag, Auschwitz and Hiroshima unmasked both evolution and civilisation, the bell tolled for universal grand theory. Relativism became the foundation of pluralism and the only remaining universal absolute is Human Rights. 
Tuori states at the outset that his objectives are to unveil the influence of the Western legal tradition in general and American legal realism in particular, on legal anthropology and primitivism and the reciprocal relationship between colonialism and anthropological research. In fact, he unravels a tapestry of theories and paradigms and shows the hegemony of Western beliefs in the human sciences; that prejudices are also beliefs; and that the Zeitgeist plays an important role.

In conclusion, a fascinating work addressing multiple facets of a variety of disciplines, which was made possible by the erudition of the author and his wide knowledge, and which enables him to write with authority on topics ranging from mancipatio to the burkha-cases. Tuori convincingly shows the relevance of a classical education, which empowers a person to ask new questions, making new associations, and - most importantly - original thought on matters touching the essence of human sciences.

Philip Thomas

Professor Extraordinarius, University of Pretoria 